\title{
Optimization on the cooling nozzles arrangement of hot rolling work roll
}

\author{
Bin Chen $^{1 *}$,Ming $\mathrm{Mao}^{2}$,Ming Song ${ }^{3}$,Guoyong Liu ${ }^{3}$, Ning Kong $^{3}$, Qingdong Zhang ${ }^{3}$, Guomin Han $^{3}$ \\ 1. Engineering Research Institute, University of Science and Technology Beijing, Beijing 100083, China \\ 2. Manufacturing Department of Maanshan Iron\&Steel Co., Ltd., Maanshan 243003, China \\ 3. School of Mechanical Engineering, University of Science and Technology Beijing, Beijing 100083, China \\ anhuichb@hotmail.com,gy_liu666@ustb.edu.cn, kongning@ustb.edu.cn, Zhang_qd@me.ustb.edu.cn
}

\begin{abstract}
The cooling nozzles arrangement is an important factor that affects the uniformity of the work roll temperature during hot rolling. In order to improve the work roll temperature distribution, a 2D calculation model of the unsteady temperature field of the work roll was established and the cooling nozzles arrangement was optimized based on the ANSYS finite element software. And it could be found that the temperature differences between the middle and the edge of the work roll would be reduced $7 \sim 8^{\circ} \mathrm{C}$ when the cooling water crowns of the work roll on F1 F7 stands were increased. Two optimization methods were adopted, one way was: the nozzle spacings of each row were the same. By changing the flow of the nozzles, the nozzles were in gradient arrangement from the middle to the edge of the roll according to the flow. The other way was: the nozzle type and flow rate of each row were the same. By changing the nozzle spacings, the nozzles were arranged from the middle to the edge of the roll according to the nozzle spacings.
\end{abstract}

Keywords-hot rolling; work roll; cooling; temperature distribution optimization; nozzles arrangement

\section{INTRODUCTION}

Due to the uneven distribution of thermal loads, the temperature distribution is uneven in every part of the work roll during hot rolling [1 2]. The uneven distribution will cause the spalling of oxide scale on the roll surface and affect the roll life. At the same time, the roll temperature is continuously changing during hot rolling, which will change the thermal expansion of the rolls and further affect the shape of the roll gap, then, the flatness quality will be changed [3 4]. Therefore, in order to control the formation of the roll oxide scale and improve the oxidation surface defects of the strip, it is necessary to study the roll temperature field and control the roll temperature distribution. And it is important for improving the roll surface quality and the strip flatness quality.

Relevant scholars had done a lot of work on the research of the roll temperature field during hot strip rolling. Ginzburg et al. used a 2D finite difference model to study the influence of the boundary conditions, the heat exchange coefficients and various design parameters (cooling water flow rate, pressure, etc.) on the work roll temperature[5]. Saboonchi et al. established a 2D finite difference model and studied the influence of the cooling water injection geometric parameters on the work roll temperature field, including the nozzle angle, the distance between the nozzle and the work roll as well as the nozzle type [6]. Abbaspour et al. studied the influence of the strip width, the strip temperature, the gap time and reduction on the work roll temperature field[7].

Domestic scholars had also done a lot of work in this field. Xuan-li Zhang et al. established a 2D axisymmetric model of the roll by the finite difference method and studied the influence of the strip width and the roll shift on the work roll thermal contour [8]. Lian-sheng Wang et al. established a 2D thermal crown model of the work roll by a new method of $2 \mathrm{D}$ alternating difference and studied the influence of rolling rhythm and strip width on the thermal crown of the work roll [9]. Chang-sheng Li et al. established a 3D temperature field model of the work roll by the finite element method and studied the variation law of the temperature in the work roll surface during hot rolling. Then, the calculation results showed that the highest temperature of the work roll during hot rolling was $593^{\circ} \mathrm{C}[10]$. Ning-tao Zhao et al. studied the influence of the rolling speed and roll shift on the temperature field and thermal crown of the work roll during the rolling of nonoriented silicon steel [11].Jing Shi of Northeastern University studied the influence of the work roll shifting strategy, the friction heat and deformation heat during hot rolling, the heat exchange coefficient between the surrounding media and the temperature distribution on the work roll temperature [12]. Peng-yan Zhang of University of Science and Technology Beijing studied the influence of the strip width, the rolling temperature, the rolling rhythm and the ambient temperature on the work roll thermal crown[13].Xiang-wei Kong simulated the temperature field of the work roll and dynamically analyzed the heating process of the work roll during hot rolling by the ANSYS finite element software [14].

However, due to the different research emphasis points, the influence of cooling nozzles arrangement on the axial temperature distribution of the work roll was not systematically studied in previous studies. Therefore, in order to improve the work roll temperature distribution, the calculation model of the 2D unsteady temperature field of the work roll was established and the cooling nozzles arrangement was optimized based on the ANSYS finite element software in this paper. And the study will provide theoretical guidance and technical support for roll cooling. 


\section{FINITE ELEMENT MODEL OF WORK ROLL TEMPERATURE} FIELD

\section{A. The establishment of finite element model}

The study of the work roll temperature field is a 3D problem. During rolling, the temperature of the work roll changes in three directions: the axial direction, the radial direction and the circumferential direction. Therefore, a 3D model should be established to calculate the work roll temperature field, but it will lead to the complexity of the solution and a huge calculation amount. So, in order to reduce the calculation amount and accelerate the solving speed, a 2D unsteady temperature field calculation model of the work roll was established based on the ANSYS finite element software, and the $3 \mathrm{D}$ problem was simplified as a $2 \mathrm{D}$ problem.

Stevens measured the off-line temperature of the work roll and found that the temperature of the work roll surface changed drastically, meanwhile, more than $99 \%$ of the work rolls had axisymmetric temperature distribution laws. Therefore, when the axial temperature distribution law of the work roll was only studied, the heat transfer along the circumferential direction was ignored while the heat transfer along the axial direction and the radial direction was considered. And the axisymmetric temperature field model of the work roll was established [15].

The axisymmetric temperature field model of the work roll was established by the Plane55 element in the ANSYS finite element software when the heat transfer along the circumferential direction was ignored, as shown in Fig.1.At the same time, the contact area between the work roll surface and the strip was mesh-refined when considering of the large temperature gradient in this area.

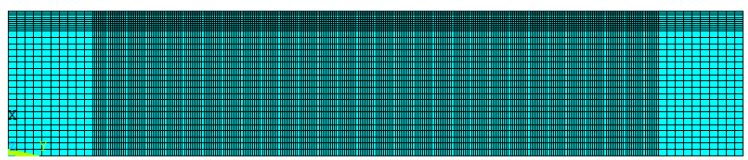

Fig. 1. Axisymmetric temperature field finite element model of the work roll
When the axisymmetric model was loaded, the loading time in each area was calculated in view of the angle of each area and the work roll speed. Then, the model was dynamically loaded according to the loading time and boundary conditions.

\section{B. The boundary conditions}

In combination with the actual rolling, the boundary conditions of the work roll in the axial direction were shown in Fig.2. In the contact area (1) between the work roll and the strip, the heat exchange forms mainly included: the heat exchange between the work roll and the strip, the water cooling and air cooling of the work roll; in the non-contact areas (2) and (3), the heat exchange forms mainly included: the water cooling and air cooling of the work roll; and the end surfaces of the work roll were set as adiabatic conditions.

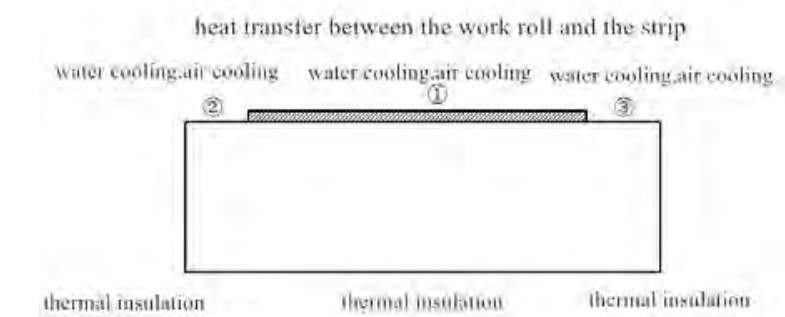

Fig. 2. Boundary conditions in the axial direction of the work roll

The heat exchange coefficients of the boundary conditions were mainly calculated by referring to related literature [16 21].

\section{THE VERIFICATION OF MODEL ACCURACY}

The 2250 production line of a steel plant was taken as the research object, and the thermophysical parameters of the work roll material mainly include the specific heat capacity, the thermal conductivity and the relationship between the Poisson ratio and the temperature, as shown in Tab.1 and Tab.2.

Tab.1 Physical parameters of high-chromium cast iron work roll

\begin{tabular}{cccccccc}
\hline & \multicolumn{7}{c}{ High-chromium cast iron } \\
\hline $\begin{array}{c}\text { Temperature } /{ }^{\circ} \mathrm{C} \\
\text { Thermal conductivity }\end{array}$ & 20 & 100 & 200 & 300 & 400 & 500 & 600 \\
$\quad 54$ & 51 & 48 & 45 & 40 & 36 & 33 \\
$\begin{array}{c}\text { Specific heat capacity } /(\mathrm{m} \cdot \mathrm{K})) \\
/(\mathrm{J} / \mathrm{Kg} \cdot \mathrm{K})\end{array}$ & 468 & 480 & 520 & 530 & 540 & 560 & 580 \\
Poisson ratio & 0.3 & 0.3 & 0.3 & 0.3 & 0.3 & 0.3 & 0.3 \\
\hline
\end{tabular}

Tab.2 Physical parameters of the infinite chilled cast iron work roll

\begin{tabular}{cccccccc}
\hline \multicolumn{7}{c}{ Infinite chilled cast iron } \\
\hline Temperature/ $\mathbb{C}$ & 20 & 100 & 200 & 300 & 400 & 500 & 600 \\
Thermal conductivity & 53 & 49 & 45 & 40 & 35 & 29 & 24 \\
$/(\mathrm{W} /(\mathrm{m} \cdot \mathrm{K}))$ & 430 & 450 & 470 & 500 & 520 & 540 & 570
\end{tabular}


$/(\mathrm{J} / \mathrm{Kg} \cdot \mathrm{K})$

Poisson ratio

0.3

0.3

0.3

0.3

0.3

0.3

0.3

In order to verify the calculation accuracy of the finite element model, after hot rolling, the cooling water was closed and the roll was pulled out for 10 minutes air cooling, then, the temperature of the roll surface was measured. The measurement tool of the roll temperature is a contact thermometric instrument. Considering of the symmetry of the work roll, the half length of the work roll was selected to measure the roll temperature and one point is measured every

$100 \mathrm{~mm}$. Fig. 3 shows a comparison of the measurement values and the calculation values of the work roll surface temperature.

It can be seen from Fig.3 that the calculation values of the work roll temperature coincide well with the measurement values, and the maximum deviation is within $2^{\circ} \mathrm{C}$. So, the calculation model in this paper can well simulate the temperature field distribution of the work roll in hot rolling.
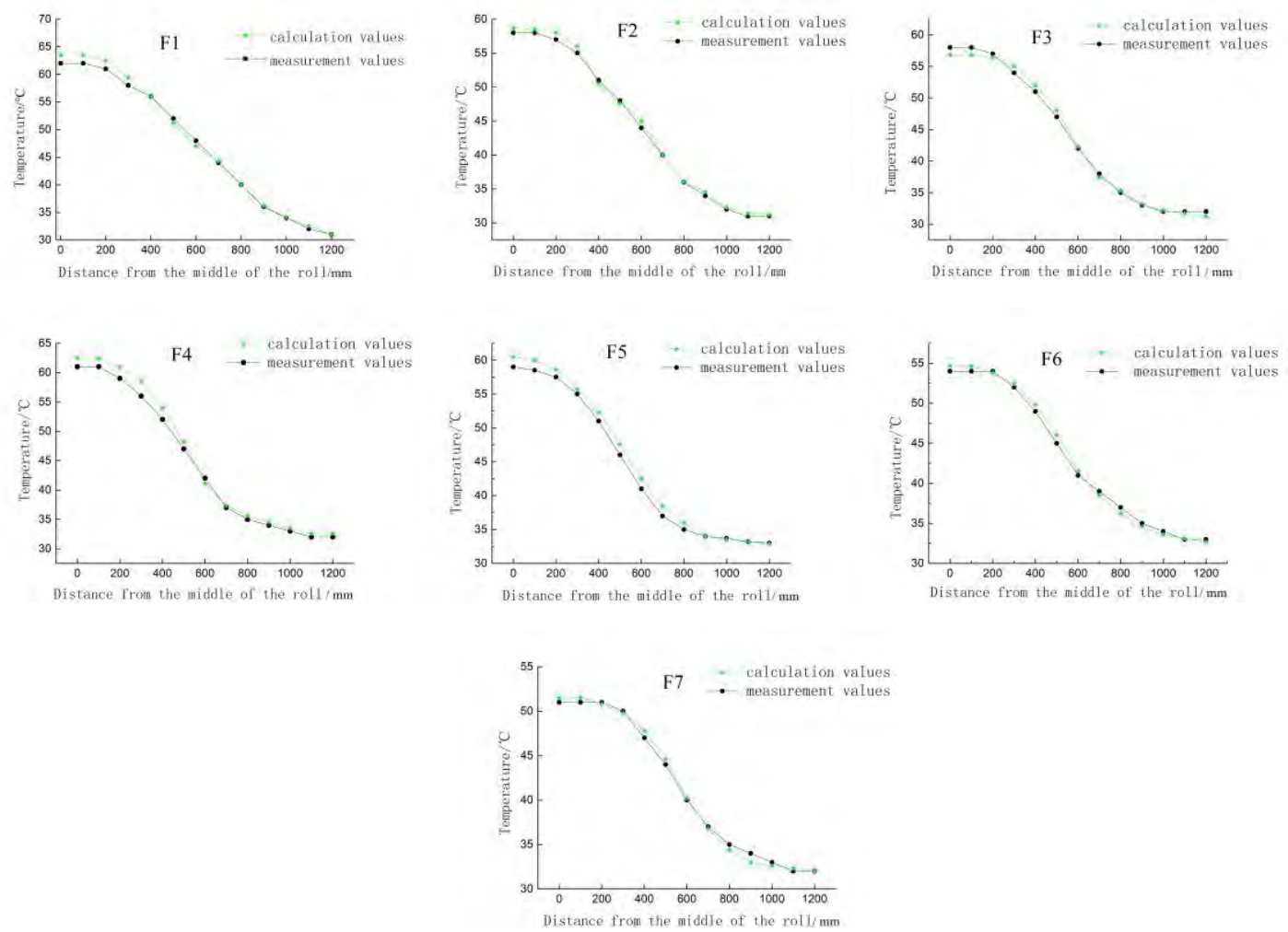

Fig. 3. Comparison between calculation values and measurement values of the work roll temperature

\section{THE OPTIMIZATION OF NOZZLES ARRANGEMENT}

The work roll of a steel plant was taken as the research object, and Fig. 4 shows the measured temperature distribution curve of the work roll 10min later off-line. From Fig.4, it can be seen that within the width of the $1200 \mathrm{~mm}$ rolled strip, the temperature differences between the middle and the edge of the work roll are large in 7 stands and the average temperature difference is within $14 \sim 19^{\circ} \mathrm{C}$. The roll temperature is closely related to the formation of the oxide scale. And the excessive temperature difference between the middle and the edge of the roll, the unreasonable temperature distribution of the roll can lead to the spalling of the oxide scale and affect the quality of the strip surface. Therefore, it is necessary to study the roll temperature field and analyze or improve the excessive temperature difference between the middle and the edge of the roll.

The cooling water of the work roll is a direct or main factor which affects the roll temperature distribution. In order to characterize the influence of the cooling water flow distribution, the water crown $C_{w}$ is proposed in this paper and defined as:

$$
C_{w}=\frac{D_{c}-D_{b}}{D_{c}} \times 100 \%
$$

$D_{c}$ Cooling water flow density in the middle of the work roll, $\mathrm{L} /(\mathrm{min} \cdot \mathrm{mm})$

$D_{b} \longrightarrow$ Cooling water flow density in the edge of the work roll, $\mathrm{L} /(\mathrm{min} \cdot \mathrm{mm})$

The work roll cooling nozzles of the steel plane were arranged in the form of equal spacing, which led to the same amount of the cooling water in the middle and the edge of the work roll and the water crown is 0 . The equal spacing arrangement of the cooling nozzles was not providing effective cooling for the situation that the heat dissipation was the worst in the middle and the best in the edge of the roll, So, it led to a 
large temperature difference between the middle and the edge of the work roll.

In order to improve the axial temperature distribution of the work roll, two optimization methods of the cooling nozzles arrangement were adopted. One way was: the nozzle spacings of each row were the same. By changing the flow of the nozzles, the nozzles were in gradient arrangement from the middle to the edge of the roll according to the flow. The other way was: the nozzle type and flow rate of each row were the same. By changing the nozzle spacings, the nozzles were arranged from the middle to the edge of the roll according to the nozzle spacings.

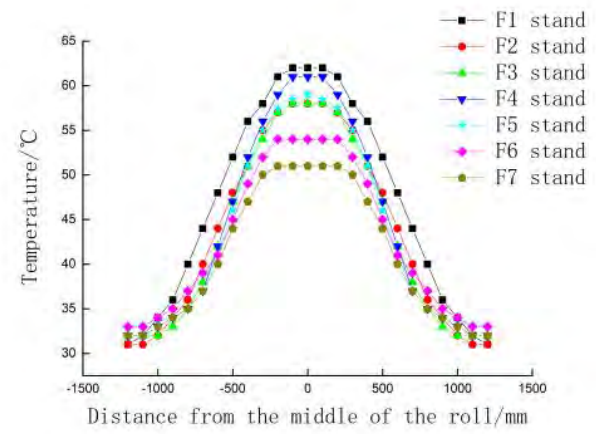

Tab.3 The optimal water crown of the roll cooling water for F1 F7 stands

\begin{tabular}{lcc}
\hline Stand & Water crown before optimization & Water crown after optimization \\
\hline F1 & $0 \%$ & $33 \%$ \\
F2 & $0 \%$ & $33 \%$ \\
F3 & $0 \%$ & $33 \%$ \\
F4 & $0 \%$ & $38.7 \%$ \\
F5 & $0 \%$ & $38.7 \%$ \\
F6 & $0 \%$ & $41.2 \%$ \\
F7 & $0 \%$ & $41.2 \%$ \\
\hline
\end{tabular}
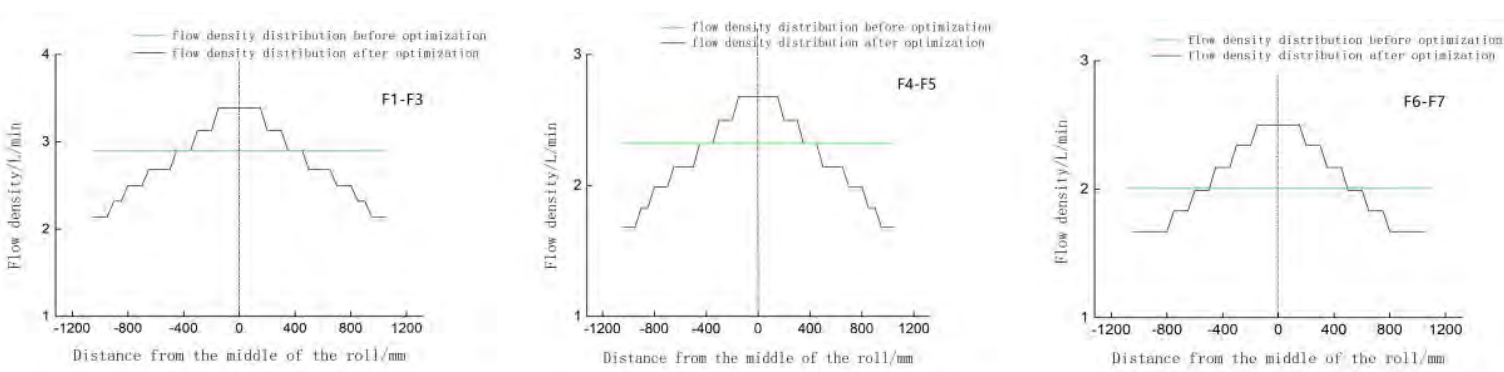

Fig. 5. The axial cooling water flow distribution of the work roll on F1 F7 stands

\section{B. The second optimization method}

The nozzles arrangement optimization method mentioned above could effectively improve the roll temperature distribution, but it also had disadvantages that the number of nozzle types was greatly increasing, which brought difficulties to the maintenance and management of the nozzles.
Therefore, the second optimization method was proposed: the nozzle type and flow rate of each row were the same. By changing the nozzle spacings, the nozzles were arranged from the middle to the edge of the roll according to the nozzle spacings. This method greatly decreased the number of nozzle 
types and brought convenience to the maintenance and management of the nozzles.

The work roll of the $2250 \mathrm{~mm}$ production line in a steel plant was taken as the research object, and the second optimization method was adopted based on the optimal water crowns of the work roll cooling water as shown in Tab.3. Tab.4 to Tab.6 are the optimization methods of the work roll cooling nozzle spacings for F1 F7 stands.

Table.4 The cooling nozzle spacings arrangement method of the work roll on F1 F3 stands

\begin{tabular}{|c|c|c|c|c|c|c|c|c|c|}
\hline & & Drive & $\rightarrow$ & Operate side & & & & & \\
\hline The number of nozzles & 4 & 4 & 5 & 5 & 7 & 5 & 5 & 4 & 4 \\
\hline $\begin{array}{l}\text { The nozzle spacings } \\
\text { before optimization/mm }\end{array}$ & 50 & 50 & 50 & 50 & 50 & 50 & 50 & 50 & 50 \\
\hline $\begin{array}{l}\text { The nozzle spacings } \\
\text { after optimization/mm }\end{array}$ & 60 & 55 & 50 & 45 & 40 & 45 & 50 & 55 & 60 \\
\hline
\end{tabular}

Table.5 The cooling nozzle spacings arrangement method of the work roll on F4 F5 stands

\begin{tabular}{|c|c|c|c|c|c|c|c|c|c|}
\hline & & rive & $\rightarrow$ & Operate side & & & & & \\
\hline The number of nozzles & 4 & 4 & 5 & 5 & 7 & 5 & 5 & 4 & 4 \\
\hline $\begin{array}{l}\text { The nozzle spacings } \\
\text { before optimization/mm }\end{array}$ & 50 & 50 & 50 & 50 & 50 & 50 & 50 & 50 & 50 \\
\hline $\begin{array}{l}\text { The nozzle spacings } \\
\text { after optimization } / \mathrm{mm}\end{array}$ & 62 & 56 & 50 & 44 & 38 & 44 & 50 & 56 & 62 \\
\hline
\end{tabular}

Table.6 The cooling nozzle spacings arrangement method of the work roll on F6 F7 stands

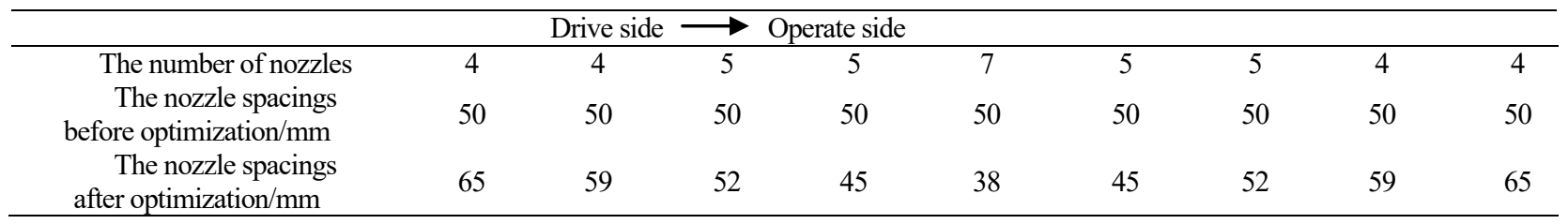

\section{TEST VERIFICATION}

In order to verify the rationality of the nozzle arrangement optimization method, the on-line rolling test was required. However, the second optimization method needed to change the nozzle spacings. Due to the limitation of the field conditions, the injection beam was not redesigned and replaced in the short term. Therefore, only the first optimization method was used to perform the on-line rolling test.

The average rolled strip width in the last hour of the rolling was $1200 \mathrm{~mm}$, in other words, the work roll was only in contact with the strip within the $1200 \mathrm{~mm}$ rolling area. Tab. 7 shows the comparison of the roll temperature distribution before and after optimization. It can be seen from Tab.7 that the average temperature difference between the middle and the edge of the off-line work roll reaches $14 \sim 19^{\circ} \mathrm{C}$ in the rolling area before optimization while it decreases $7 \sim 8^{\circ} \mathrm{C}$ in the rolling area after optimization. It shows that the axial temperature distribution of the work roll was improved and the temperature difference between the middle and the edge of the work roll was decreased, which is important for improving the thermal crown of the work roll. So, the optimization methods in this paper are reliable and reasonable in this paper.

The optimization methods in this paper greatly improved the axial temperature distribution of the work roll and reduced the temperature difference between the middle and the edge of the work roll, and these are important for controlling the formation of the oxide scale, improving the oxidation surface defects and the surface quality of the strip.

Table.7 Differences in the axial temperature distribution of work roll before and after optimization

\begin{tabular}{|c|c|c|c|c|c|c|c|}
\hline Stand & $\mathrm{F} 1$ & $\mathrm{~F} 2$ & F3 & $\mathrm{F} 4$ & F5 & F6 & F7 \\
\hline $\begin{array}{l}\text { Average temperature difference between the middle } \\
\text { and the edge of the work roll before optimization }\end{array}$ & $19^{\circ} \mathrm{C}$ & $19^{\circ} \mathrm{C}$ & $18^{\circ} \mathrm{C}$ & $16^{\circ} \mathrm{C}$ & $16^{\circ} \mathrm{C}$ & $15^{\circ} \mathrm{C}$ & $14^{\circ} \mathrm{C}$ \\
\hline $\begin{array}{l}\text { Average temperature difference between the middle } \\
\text { and the edge of the work roll after optimization }\end{array}$ & $11^{\circ} \mathrm{C}$ & $11^{\circ} \mathrm{C}$ & $10^{\circ} \mathrm{C}$ & $9^{\circ} \mathrm{C}$ & $9^{\circ} \mathrm{C}$ & $8^{\circ} \mathrm{C}$ & $7^{\circ} \mathrm{C}$ \\
\hline
\end{tabular}




\section{CONCLUSIONS}

The calculation model of the axial 2D unsteady temperature field of the work roll was established based on the ANSYS finite element software. Meanwhile, the cooling nozzles arrangement was optimized to improve the work roll temperature distribution, and the following conclusions are obtained:

(1) The temperature difference between the middle and the edge of the work roll will decrease $7 \sim 8^{\circ} \mathrm{C}$ when the water crowns of the work roll cooling water for $\mathrm{F} 1 \sim \mathrm{F} 7$ stands are: $33 \%, 33 \%, 33 \%, 38.7 \%, 38.7 \%, 41.2 \%, 41.2 \%$.

(2) In order to improve the temperature distribution of the work roll, the first optimization method(the nozzle spacings of each row were the same. By changing the flow of the nozzles, the nozzles were in gradient arrangement from the middle to the edge of the roll according to the flow) was adopted to optimize the cooling nozzles arrangement. And the cooling nozzles arrangement optimization method was proved to be reliable and reasonable by the rolling test.

(3) In order to improve the temperature distribution of the work roll, the second optimization method(the nozzle type and flow rate of each row were the same. By changing the nozzle spacings, the nozzles were arranged from the middle to the edge of the roll according to the nozzle spacings) was adopted to optimize the cooling nozzles arrangement. And the cooling nozzle spacings arrangement method of the work roll for F1 F7 stands was proposed in a steel plant.

\section{REFERENCES}

[1] W. Guo, Q. N. Wang, F. Q. Wang, F. Li. Research and application of optimization of thermal balance of work roll in hot strip mill[J].China Metallurgy, 2017,27 (07): 50.

[2] X. L. Shen, X .P. Mao, Production Technology of Ultra-Thin Gauge Hot Rolled Strips[J]. China Metallurgy, 2011,21 (07) :23

[3] J. F. Cheng, Z. D. Liu, G. P. Tang. Analysis on Factors Affecting Thermal Evolution of Strip During Runout Table Cooling[J].Hot Working Technology, 2011,20 (40) :29.

[4] Z. M. Yin, S. J. Liu. Analysis and Experimental Investigation of Oil Jet Flow of Main Reducer Gear based on Flowmaster[J].Journal of Mechanical Transmission, 2017,01:82-86.

[5]Ginzburg V B, Bakhtar F A, Issa R J. Application of Coolflex model for analysis of work roll thermal conditions in hot strip mills[J]. Iron \& Steel Engineer, 1997, 74(11):38.
[6]A Saboonchi, M Abbaspour. Changing the geometry of water spray on milling work roll and its effect on work roll temperature[J]. Journal of Materials Processing Tech, 2004, 148(1):35.

[7] L. M. Lu, G. W. Zhang. FEM of Temperature Field of Rolling-sliding Compound Bearing[J].Journal of Mechanical Transmission, 2016,04:139-142.

[8]X. L. Zhang, J. Zhang, X. Y. Li, et al. Analysis of the thermal Profile of work rolls in the hot strip rolling process[J]. Journal of University of Science and Technology Beijing(English Edition),2004,11(02):173.

[9]L. S. Wang, Q. Yang, A. R. He, et al. Improvement of prediction model for work roll thermal contour in hot strip mill [J]. Journal of Central South University of Technology,2010,17(06):1251.

[10]C. S. Li, H. L. Yu, G. Y. Deng, et al. Numerical simulation of temperature field and thermal stress field of work roll during hot strip rolling $[\mathrm{J}]$. Journal of Iron and Steel Research International, 2007, 14(5):18.

[11]N. T. Zaho, J. G. Cao, J. Zhang, et al. Work roll thermal contour predication model of nonoriented electrical steel sheets in hot strip mills[J]. Journal of University of Science and Technology Beijing(English Edition),2008,15(3),352.

[12] J. Shi. Thermal Crown Calculation Model and Off-line Simulation Analysis of Work Roll[D]. Northeastern University, 2002.

[13] P. Y. Zhang. Research on Roll Temperature Field and Thermal Crown in Hot Strip Mill of Wide Strip[D]. University of Science and Technology Beijing, 2007

[14] P. Y. Zhang. Research on Roll Temperature Field and Thermal Crown in Hot Strip Mill of Wide Strip[D]. University of Science and Technology Beijing, 2007.

[15]P. G. Stevens, K. P. Iven, P. Harper. Increased work-roll life by improved roll-cooling practice[J].journal of iron and steel research international,1971,(1):1.

[16]Hlady C O, Brimacombe J K, Samarasekera I V,et al. Heat transfer in the hot rolling of metals [J].Metallurgical and Materials Transaction B, 1995,26(10):1019.

[17]Sun C G, Hwang S M, Yun C S, et al. Investigation of thermomechanical behavior of a work roll and of roll life in hot strip rolling[J]. Metallurgical and Materials Transactions A, 1998, 29(9):2407.

[18]S. Serajzadeh, Y. Mahmoodkhani, A combined upper bound and finite element model for prediction of velocity and temperature fields during hot rolling process[J]. International Journal of Mechanical Sciences, 2008,50(9): 1423.

[19] G. B. Tang, Z. D. Liu, Y. L. Kang, et al. Simulation of Thermal Evolution of Strip and Determination of Heat Transfer Coefficient in Deformation Zone During Hot Rolling[J],Iron \& Steel, 2006,41 (05) :36.

[20]S.M. Hwang, C.G. Sun, S.R. Ryoo, et al. An integrated FE process model for precision analysis of thermo-mec hanical behaviors of rolls and strip in hot strip rolling $[\mathrm{J}]$. Computer Methods in Applied Mechanics \& Engineering,2002, 191 (37):4015.

[21]D Benasciutti, E Brusa, G Bazzaro. Finite elements prediction of thermal stresses in work roll of hot rolling mills[J]. Procedia Engineering , 2010 2(1):707. 